\author{
St udi a Philosophic a \\ Wr a t i s l a vi e n s i a \\ vol. XVI, fasc. 2 (2021) \\ https://doi.org/10.19195/1895-8001.16.2.8
}

\author{
JERZY LUTY \\ ORCID: 0000-0002-2254-9526 \\ Uniwersytet Wrocławski
}

\title{
Świat sztuki i czas ewolucyjny - dlaczego estetyka współczesna boi się unaukowienia*
}

\author{
The art world and the time scale of evolution: \\ why contemporary aesthetics is afraid of being scientific
}

\begin{abstract}
The criticisms I address in this article provoke questions about the very nature of aesthetic discourse and its relation to scientific approach in art theory. In the article, I try to respond to the author who criticizes me (and evolutionary aesthetics) for disliking avant-garde art and, worse, contemporary aesthetics. I also try to explain that I am not a biological determinist, that I do not consider art an evolutionary adaptation, that I do not practice reductionism, and that I know how evolutionary mechanisms work. I also describe the reasons why the contemporary aesthetics, which the critic represents, is afraid of being scientific, and what this has to do with the need for prestige and belonging to the art world.
\end{abstract}

Keywords: evolutionary aesthetics, contemporary aesthetics, art world, institutional art, adaptation, scientifically informed aesthetics, prestige-driven bias

\footnotetext{
* Praca powstała w wyniku realizacji projektu badawczego nr 2019/35/B/HS1/02293 finansowanego ze środków Narodowego Centrum Nauki.
} 
Estetyka dla artystów jest tym, czym ornitologia dla ptaków.

Barnett Newman ${ }^{1}$

Słowem, wszyscy fabrykanci retoryk, poetyk i estetyk wydają mi się durniami!

Gustaw Flaubert ${ }^{2}$

Zaprzeczanie faktu uniwersalności różnych odmian sztuki wpycha refleksję estetyczną w relatywistyczne nisze kultur i instytucji. Niektórym jest to na rękę. „Nie ma ucieczki od instytucji sztuki" — głoszą współcześni krytycy sztuki (w domyśle: bez niej nie istniejemy), ,każdy dyskurs artystyczny i estetyczny to wypadkowa ideologii, niepisanych reguł, które dążą do dominacji" — wtórują im estetycy. Widziana z tej perspektywy nauka to (jeszcze jedna) ideologia, zaangażowana w spory sztuki i jej enigmatycznych antagonistów. Traktowanie nauki w ten sposób to typowy przykład postmodernistycznego pomieszania pojęć, wciąż obecnego w akademickim obiegu współczesnej humanistyki (choć nie tylko jej; ostatnio głośno jest o amerykańskim podręczniku do nauczania matematyki, którego autorzy stawiają sobie za cel: „dekonstrukcję rasizmu w matematyce i przygotowanie się do nauczania antyrasistowskiej matematyki"). Mówi się ostatnio o zjawisku grievance studies — „badaniach roszczeniowych” albo „pretensjologii stosowanej” — określając w ten sposób zbiorczo niektóre nauki humanistyczne i społeczne. A zatem: postępowa algebra? Chrześcijańska astronomia? Francuska fizyka? A może reakcyjna biologia? Z pewnością zaś instytucjonalna sztuka — taka, która z nakazu jej administratorów nie może obejść się bez teorii, ale jest za pan brat z ideologią. Według której „gust jest spontanicznie mnogi”, a sztuka dedykowana indywidualnemu odbiorcy, który wszelkim próbom naukowego wyjaśnienia nadaje łatkę „permanentnie obnażającej krytyki”, toczonej przez „walczącego za ogłupiałe masy wybrańca". Wydaje się, że na nikim nie robi już dziś wrażenia afera Sokala (czy nawet jego wersja „do kwadratu” z 2018 roku). „Zasłona dymna pustki myślowej?”, „Nowe szaty cesarza?" A może po prostu obrona instytucjonalnej pozycji krytyka za cenę naukowej wiarygodności?

Uwagi krytyczne, do których pragnę odnieść się w niniejszym tekście, mają nieco inny charakter niż pozostałe krytyki ${ }^{3}$, ponieważ nie tylko wpisują się w opisany powyżej trend, ale prowokują również do pytań o samą naturę dyskursu estetycznego oraz jego stosunek do unaukowienia wiedzy o sztuce. Agnieszka Bandura, estetyczka specjalizująca się w badaniu współczesnych relacji teorii i praktyki artystycznej — w nieczęsto spotykanym w akademickich dyskusjach tonie, który kojarzy się raczej z zaangażowaną krytyką artystyczną niż z merytoryczną dyskusją — oskarża mnie (oraz estetykę ewolucyjną) o to, że nie lubię sztuki awangardowej oraz, co gorsza, estetyki współczesnej. Lista zarzutów jest dłuższa.

\footnotetext{
1 Barnett Newman: Selected Writings and Interviews, J.P. O'Neill (ed.), New York 1990, s. 25.

${ }^{2}$ G. Flaubert, Bouvard i Pècuchet, tłum. W. Rogowicz, Warszawa 1955, s. 154.

${ }^{3}$ Odpowiedź na nie znajdzie czytelnik w niniejszym numerze.
} 
Według Autorki jestem również biologicznym deterministą (bo rzekomo uważam sztukę za ewolucyjną adaptację), uprawiam redukcjonizm, a także nie rozumiem, jak działają mechanizmy ewolucyjne. Choć pod pewnymi względami może nie być to łatwe (przede wszystkim ze względu na dość chaotyczny charakter wywodu polemistki), postaram się wyczerpująco odpowiedzieć na zarzuty Autorki (zahaczając przy okazji o kilka pomniejszych kwestii).

Odnosząc się do wspomnianych uwag, chciałbym poczynić kilka zastrzeżeń. Tekst komentarza (zwłaszcza w części odwołującej się bezpośrednio do treści mojej książki), oprócz zaskakującego jak na dyskurs naukowy tonu wypowiedzi, mieni się szeregiem merytorycznych nieporozumień i przeinaczeń (na przykład gdy nawiązuje do odniesień do teorii psychologicznych i antropologii ewolucyjnej, gdzie uderza mocno wybiórcze traktowanie ich twierdzeń). Choć wiele z zarzutów, które formułuje Autorka nie odnosi się wprost do zawartości książki (jest raczej swoistą projekcją ,skarg i zażaleń”, która w podejściu ewolucyjnym dostrzega źródła wszelkich możliwych nieszczęść, jakie trapią estetykę współczesną. A może to programowa postawa „permanentnego niezadowolenia”, nad którą rozwodzi się Autorka, każe jej widzieć w drodze „naznaczonej niepowodzeniem i przykrością” swoistą strategię pisarską, która jak ulał wpisuje się w koncept grievance studies sformułowany przez Pluckrose'a, Lindsay i Boghossiana, inicjatorów afery „Sokala do kwadratu”), czuję się w obowiązku przynajmniej niektóre z nich skomentować.

Zacznę od kwestii estetycznych. Mniej więcej jedną trzecią tekstu zajmuje emocjonalna obrona sztuki awangardowej przed rzekomą jej deprecjacją przez estetykę ewolucyjną. Autorka powołuje się na fragment rozdziału 5 Sztuki jako adaptacji, a dokładnie na wyimek, w którym poddaję krytyce teoretyczne uwikłania współczesnych estetyk w opisy sztuki awangardowej. Podkreślam — estetyk, a nie samej sztuki (problem z rozpoznaniem tej dystynkcji nieprzerwanie towarzyszył mi podczas lektury tekstu Bandury). Rzekomo wrogim wobec awangardy implikacjom zdania ze strony 149 Autorka przeciwstawia dość nieskładną, choć wygłoszoną w bardzo żarliwym tonie, obronę swej „ukochanej” sztuki przed... No właśnie przed czym? W kolejnych fragmentach uchyla nieco rąbka tajemnicy, pisząc, że to jej własny dyskurs emanuje aurą ,niepowodzenia i przykrości”. Efektem tej emanacji jest stwierdzenie, że podejście ewolucyjne jest redukcjonistyczne i deterministyczne, ponieważ z premedytacją nie dostrzega, że prawdziwa sztuka „porządkuje” i „stabilizuje” "chaotyczność wciąż przyczajoną w sercu człowieka"4, pomimo że „niespełnienie stanowi jedną z głównych sił napędowych twórczości artystycznej”. Być może tak jest, być może nie, nie wiem. Sprawdźmy to, projektując odpowiednie badania. Autorka, która operuje dość metaforycznym stylem, woli jednak szarżować. Daje przy okazji liczne dowody raczej pobieżnej znajomości problematyki, którą referuje (i recenzuje), na przykład wtedy, gdy definiuje podejście ewolucyjne jako to, które widzi w adaptacjach ,sprawnie działające, efektywne, niezawodne

${ }^{4}$ A. Bandura, Twórczość jako adaptacja? Sztuka zagrożona wyginięciem, „Studia Philosophica Wratislaviensia" 16 [1] (2021), s. 45. 
i zracjonalizowane mechanizmy - nie tylko zapewniajace przetrwanie, ale i ciągłość gatunku - oraz celowo zaprogramowane adaptowanie się do rzeczywistości”.

Nie znam żadnego ewolucjonisty, który twierdziłby, że mechanizmy ewolucyjne, które odziedziczyliśmy po naszych przodkach, są dziś adaptacyjne lub optymalne (bo w znacznej mierze nie są). Albo że determinują zachowanie. Albo że ewolucja to proces celowy. Albo że jeśli jakieś cechy pojawiły się w efekcie działania procesów ewolucyjnych, to oznacza to, że powinny one istnieć i być propagowane (znów mamy tu do czynienia, jak u Huculaka, z klasycznym przykładem błędu naturalistycznego). Nie mówiąc już o wyjątkowo niefortunnym sformułowaniu, że w ewolucji chodzi o przetrwanie gatunku, albo o dość kuriozalnych uwagach, w stylu: „gatunek ludzki, adaptuje się do (wrogiej) rzeczywistości”, „ewolucyjnie szkodliwa aberracja”, „przetrwają the fittest' itp. ${ }^{6}$ Tego typu stwierdzenia, rodem z dziewiętnastowiecznych traktatów, od dawna nie wchodzą w skład żadnego poważnego dyskursu naukowego (tego typu nieadekwatnościom, bardzo charakterystycznym dla programowych krytyk antyscjentystycznych, poświęcam w książce kilka obszernych fragmentów) ${ }^{7}$.

Dominujące dziś ujęcia nie tylko wskazują na obecność zjawiska tak zwanej ewolucyjnej inercji (które każe widzieć w cechach niegdyś adaptacyjnych kognitywne mechanizmy „uprzykrzające” adaptowanie się do aktualnych zmian kulturowych i cywilizacyjnych) czy na rolę przypadku jako podstawowej siły napędowej procesów ewolucyjnych (co jest głównym motywem religijnie motywowanych krytyk teorii Darwina; tak, Francis Jacob ma tu rację), ale nieustannie podkreślają istotność wpływu kultury na ekspresję cech genotypowych. Oddajmy głos ekspertom:

Determinizm genetyczny rozumie się jako stanowisko głoszące, że jedyną determinantą zachowania jest genotyp. Sęk w tym, że żaden biolog takiego stanowiska nie przyjmie: geny mogą determinować zachowanie jedynie pośrednio, a mianowicie za pośrednictwem fenotypu. Fenotyp zaś wzrasta w określonym środowisku, które go kształtuje. U człowieka najważniejszym elementem tego środowiska jest kultura ${ }^{8}$.

Dutton: „Prawda ludzkiej sytuacji jest taka, że jesteśmy biologicznie zdeterminowanymi organizmami, które żyją w kulturze. To, że jesteśmy istotami kulturowymi jest częścią tego, co jest zdeterminowane przez nasze geny"9. Dissanayake: „Pojęcie funkcji adaptacyjnej nie musi być sztywne, hierarchiczne czy deterministyczne [...]. Wręcz przeciwnie - idea adaptacjonizmu jest taka, że zachowania są rozwiniętymi predyspozycjami, które mogą być wyrażone w różnych kulturowych i indywidualnych przejawach"10. W kwestiach zawiłości pojęciowej nauk ewolucyj-

\footnotetext{
5 Ibidem, s. 46.

6 Ibidem, s. 47.

${ }^{7}$ Por. J. Luty, Sztuka jako adaptacja: uniwersalizm w estetyce ewolucyjnej, Kraków 2018, s. 14.

${ }^{8}$ M. Miłkowski, Perspektywy ewolucjonistyczne w badaniach społecznych, [w:] Oprogramowanie rzeczywistości społecznej, M. Gdula, L.M. Nijakowski (red.), Warszawa 2014, s. 192.

${ }^{9}$ D. Dutton, Sztuka i rzeczywistość ludzka, tłum. J. Luty, Racjonalista.pl, www.racjonalista.pl/ kk.php/s,6977 (dostęp: 18.08.2021).

${ }^{10}$ E. Dissanayake, The Arts after Darwin. Does art have origin and adaptive function, [w:] World Art Studies: Exploring Concepts and Approaches, K. Zijlmans, W. van Damme (eds.), Amsterdam 2008 , s. 245.
} 
nych, polecam zwłaszcza artykuł Ryszkiewcza, na który powołuję się w tekście głównym. Gdyby Autorka miała kłopot z wyborem rzetelnych źródeł naukowych (ciekawych nie tylko z punktu widzenia historii nauki, a niepozostających w duchu spencerowskiego socjaldarwinizmu; artykuł Ryszkiewicza jest tekstem popularnonaukowym), odsyłam do bogatej bibliografii, znajdującej się na końcu książki.

Swój komentarz wieńczy Bandura czymś w rodzaju ultimatum, w którym nawiązuje po raz kolejny do nienależytej, jej zdaniem, atencji piszaccego te słowa wobec sztuki współczesnej (oraz jej nieodłącznego kompana — estetyki współczesnej): albo zaczniesz interesować się nami, albo teoria, którą lansujesz zniknie w odmętach historii — ogłasza w nieco schizofrenicznym dictum. Albowiem: „Jak mawiał klasyk: » Teorie mijają. Żaba zostaje «"11. Cóż, chciałoby się dodać: i pomidor tė̇. Nie jestem pewien, jaki jest logiczny związek między ewentualnym objęciem przez piszącego te słowa większą atencją subiektywnych dywagacji współczesnego estetyka, a rzeczywistą adekwatnością recenzowanej teorii do opisywanych przez nią zjawisk, ale być może nie w tym rzecz, aby doszukiwać się tu logiki. Niemniej jednak w przeciwieństwie do Bandury nie jestem przesadnie pewny, że sztuka awangardowa przetrwa próbę czasu $^{12}$ (sądzę z kolei, że estetyka współczesna zorientowana na aktualne trendy — już niekoniecznie). Żywię natomiast przekonanie graniczące z pewnością, że jeśli przetrwa człowiek, to wraz z nim zachowane zostanie wszystko to, w co wyposażyła go ewolucja. Łącznie z jego skłonnością do neurozy, artystycznego kunsztu i estetycznej przesady. Sęk bowiem w tym, że teoria, która tyle rumieńców wzbudza, z powodzeniem sobie radzi nie tylko z ziębami, żabami i pomidorami, ale i ze wspaniałymi emanacjami ludzkiego umysłu, takimi jak sztuka i jej wytwory.

Bandura zarzuca mi, że estetyka ewolucyjna, tak ją przedstawiam, jest „totalizująca” i nie chce być „obok/z innymi”. Wypada mi jedynie żałować, że nie miała okazji pochylić się nad fragmentami, w których epatuję „pojednawczym” stosunkiem estetyki ewolucyjnej do ujęć konkurencyjnych, na przykład gdy piszę, że: „współczesny ewolucjonizm humanistyczny (evolutionary humanities), posądzany o genetyczny determinizm, redukcjonizm lub co najmniej o biologizm, nie rości sobie pretensji do ustanowienia jedynie słusznego programu badawczego i rozciągnięcia go na odmienne metodologicznie i dziedzinowo obszary wiedzy"13. Wsparty przekonaniem o profetycznej mocy Deweyowskiego pragmatyzmu, które wyrażam w jednych tekstów, poświęconym metateoretycznym uwikłaniom ewolucyjnych teorii sztuki, twierdzę na przykład, że: „Współczesne nauki humanistyczne z uwagi na dominujace w nich nurty i tendencje [...] nie dysponuja wystarczająco rozbudowaną (i elastyczną) aparaturą pojęciową, która byłaby w stanie zasymilować dane i fakty nauk przyrodniczych"14. Jednocześnie

11 A. Bandura, Twórczość jako adaptacja?, s. 48.

${ }^{12}$ Nadzieja Adorno, że robotnik idący do fabryki będzie wygwizdywał dodekafoniczne kompozycje Schoenberga, wydaje się ze wszech miar złudna.

13 Por. J. Luty, Sztuka jako adaptacja, s. 39.

14 J. Luty, Estetyka ewolucyjna: sztuka jako adaptacja w ujęciu międzykulturowym, „Estetyka i Krytyka" 21 (2011), s. 102. 
pokutujące u humanistów nawyki pojęciowe, które, wykształcane latami, powodują wrażenie nieprzekładalności i niewspółmierności obu dziedzin (oraz zwykle nieuzasadniony zarzut redukcjonizmu), nie sprawiają jednak bynajmniej, że nachodzenie na siebie pozornie nieprzystających dyskursów nie może być twórcze i ożywcze, a porozumienie — niemożliwe do osiągnięcia. Dowodzi tego przede wszystkim dynamiczny rozwój studiów biokulturowych (biocultural studies), który pokazuje, że traktując przejawy ludzkiego doświadczenia nie tylko naturalistycznie, ale i zdroworozsądkowo, można pozostawać wiernym zarówno humanistycznej skłonności do uwypuklania różnic, jak i postulatowi naukowej ścisłości ${ }^{15}$.

Jak pisał w zdroworozsądkowym duchu filozoficznego instrumentalizmu John Dewey, antycypując bolączki współczesnych estetyk: „Teorie, które izolują sztukę, oraz sądy o sztuce przez uznawanie ich za dziedzinę odrębną, oderwaną od innych przejawów doświadczenia, nie wiążą się w sposób istotny z przedmiotem, jakim się zajmują"16. Cóż z tego, że izolują, cóż z tego, że oderwane od doświadczenia, cóż z tego, że nie wiążą? Grunt, żeby estetyki współczesne emanowały duchem epoki (antropocen, kryzys postpandemiczny), kultywowały przynależność instytucjonalną, a przy okazji wyrażały nastrój piszącego, często daleki od poznawczego optymizmu. Cytat: „Nasze codzienne doświadczenia nie są w stanie sprostać i dorównać syntetycznym pojęciom tworzonym przez mózg, co zazwyczaj prowadzi do stanu permanentnego niezadowolenia”. I dalej: „Droga ta naznaczona jest [...] niepowodzeniem i przykrością (przykrością — dodam — która nie jest postrzegana jako przeszkoda możliwa do przezwyciężenia, lecz również, a może przede wszystkim, jako immanentna cecha kondycji ludzkiej, określająca istotę człowieczeństwa)"17. Nic, tylko tworzyć teorię, która w pełni wyrazi to doświadczenie. A zatem: do dzieła.

Zagłębiając się w wywód Bandury, raz po raz można odnieść wrażenie, że mamy do czynienia z pomieszaniem teorii i przedmiotu jej badań; jak gdyby sztuka i dyskurs jej poświęcony niczym się w istocie nie różniły. Szarża w obronie sztuki awangardowej (której nikt tu de facto nie atakuje, ponieważ z pewnych oczywistych powodów nie znajduje się ona w centrum zainteresowania estetyk ewolucyjnych) czy domaganie się przez Autorkę atencji (nie wiadomo jeszcze tylko: dla sztuki czy dla teorii?) to wrażenie jedynie potęgują. Potwierdzają też funkcjonujący w powszechnej opinii stereotyp estetyki współczesnej. Pragnę zaznaczyć, że sam wielokrotnie mu ulegałem i sądzę, że stanowi on negatywny wyznacznik naszej dyscypliny. W dosadny sposób wyraża go Flaubertowski Bouvard (o czym w dalszej części tekstu), a nieco bardziej łagodnie Bence Nanay, gdy pisze, że estetyka to dyscyplina nie tylko izolowana w obrębie filozofii, ale też niemodna w kręgach kulturoznawców czy historyków sztuki - które postrzegaja ją jako działalność raczej bezcelową, a w najlepszym razie będącej stratą czasu ${ }^{18}$. Któż z nas, estetyków, nie solidaryzuje się z Nanayem, gdy ten, będąc na wyjeździe konferencyjnym, zagajony przez fryzjera unika ujawnienia celu wizyty, aby nie być uznanym za przedstawiciela

15 Por. J. Luty, Sztuka jako adaptacja, s. 9.

16 J. Dewey, Art as Experience, New York 1934, wyd. pol. Sztuka jako doświadczenie, tłum. A. Potocki, Wrocław 1975, s. 14 .

17 A. Bandura, Twórczość jako adaptacja?, s. 46.

18 Por. B. Nanay, Aesthetics as philosophy of perception, OUP (2016), s. 3. 
branży kosmetycznej albo innego demiurga przemysłu urodowego, a w najgorszym razie nie zostać posądzonym o jakąś przykrą dewiację intelektualną.

Pojawiający się w tekście zarzut o brak atencji dla sztuki najnowszej to przejaw takiego właśnie stanu ducha. Zarzut uważam za chybiony nie tylko dlatego, że w swojej książce nie uprawiam krytyki sztuki awangardowej (wspomniany cytat ze strony 149 zawiera krytykę sposobu pisania o sztuce, a nie samej sztuki), ale również dlatego, że byłoby to niezgodne z tym, co proponuje estetyka ewolucyjna. Przychylny każdej formy sztuce jest Dutton, choć, co istotne, podaje w wątpliwość wyjaśniająca moc teorii, które w centrum swych rozważań stawiają dokonania awangardy (w tym sztukę Duchampa, którą nota bene bardzo sobie ceni, co akurat nie powinno nikogo dziwić, biorąc pod uwage uniwersalistyczne ambicje duttonowskiej estetyki). Jego konstatacja jest tu zresztą stosunkowo zwięzła i mało kontrowersyjna:

Zamiast pytać, jak to jest, że ready-mades Duchampa są dziełami sztuki, zapytajmy co sprawia, że Symfonia Pastoralna jest dziełem sztuki. Dlaczego Sen Nocy Letniej jest dziełem sztuki? Dlaczego Duma $i$ Uprzedzenie jest dziełem sztuki? Spójrzmy najpierw na niekwestionowane paradygmatyczne przypadki i odkryjmy, co one mają ze sobą wspólnego [...] Lepiej najpierw zrozumieć je i dopiero następnie analizować modernistyczne eksperymenty i prowokacje, takie jak cudowne dzieła Duchampa ${ }^{19}$. [Gdzie znajdujemy tu brak atencji? I dalej:] Uważam Duchampa za płomiennego geniusza, ale nasze uznanie dla niego musi zawierać rozpoznanie faktu, że w swoich niektórych pracach eksperymentował on w sposób zamierzony, aby oburzać i prowokować ludzi poprzez domyślne zapytywanie o to, jakie są granice sztuki ${ }^{20}$.

Prawdą jest, że sztuka modernizmu nie stoi w centrum zainteresowań estetyki ewolucyjnej, która uznaje ją za formę nie w pełni reprezentatywną dla ukształtowanego w procesie ewolucji umysłu Homo sapiens (ze względu na niedawny czas jej pojawienia się w historii ludzkości). Nie znaczy to jednak, że nie ma dla niej żadnego znaczenia. Zupełnie jak Dutton (a w przeciwieństwie na przykład do Scrutona) pozostaję miłośnikiem sztuki abstrakcyjnej, eksperymentalnej i konceptualnej $^{21}$. Do jej właściwego odbioru nie są mi jednak potrzebne: instytucjonalna teoria Dickiego czy teorii ,końca sztuki” Danto. Jako teoretykowi zdecydowanie bliżej mi do postawy niezamykania się na potoczne, rudymentarne czy nie-elitarne doświadczenie artystyczne i artyfikacyjne twórców z poza świata sztuki (niebędące w smak estetykom-elitarystom). Nie uważam przy tym, że modus miłośnika sztuki (albo członka instytucji świata sztuki) w jakikolwiek sposób pomoże mi w trzeźwej ocenie reprezentowanych przez nią osiągnieć. Przyznaję sobie prawo do krytyki niektórych współczesnych form dyskursu poświęconego sztuce, zwłaszcza, gdy uważam je za mało inspirujące teoretycznie, nienaukowe, czyli pozbawione mocy wyjaśniającej, i które - żeby raz jeszcze przywołać nieco bezceremonialną uwagę Duttona - bywają często ,niczym więcej, niż tylko zasłoną dymną kompletnej

${ }^{19}$ D. Dutton, Sztuka i rzeczywistość ludzka.

${ }^{20}$ Ibidem.

${ }^{21} \mathrm{~W}$ sensie teoretycznym dałem temu wyraz, jak sądzę, wielokrotnie, na przykład w książce o Cage'u (J. Luty, John Cage. Filozofia muzycznego przypadku, Wrocław 2011); autorzy recenzji podkreślali, że ,autor wyraźnie sympatyzuję" ze swoim protagonistą i wyznaczanymi przez niego kierunkami artystycznych i filozoficznych poszukiwań. 
pustki myślowej - nowymi szatami cesarza"22. Szkodzą przy tym zarówno sztuce, jak i dyskursowi, który reprezentuje przecież „nowojorskie peryferia sztuki”.

Określenie powyższe, na które Autorka tak bardzo się zżyma, zniekształcające oryginalną intencję Arthura Danto (dobrego ducha nowojorskiej awangardy), zostało przeze mnie ukute z premedytacją (a nic tak nie łechce próżności autora, jak złapanie wyrobionego czytelnika w sidła prowokacji). Jest mianowicie zaproszeniem do przeprowadzenia eksperymentu myślowego, polegającego na wyobrażeniu sobie, że oto nagle nowojorska awangarda ląduje na peryferiach, a obowiązujące w hermetycznym świecie sztuki hierarchie ulegają odwróceniu. Zamysł, jaki towarzyszył temu zabiegowi był trojaki. Po pierwsze, chciałem zwrócić uwagę na ewolucyjną (czy antropologiczną) skalę czasową, w której estetyka znaturalizowana umieszcza uniwersalną, egalitarną ludzką skłonność do zachowań artystycznych (na tej skali nowojorski establishment artystyczny zaledwie niezdarnie raczkuje). Po drugie, pragnąłem wskazać na dość powszechną i moim zdaniem, szkodliwą tendencję do wyolbrzymiania znaczenia i wagi „teraźniejszości” w tworzeniu teorii (można, rzecz jasna, ulegać nowym trendom, ale żeby od razu tworzyć dla nich nowe teorie?). W końcu, last but not least, określenie to zawiera niejawną krytykę pewnej strategii teoretyczno-estetycznej, za którą kryje się szczególny rodzaj snobizmu, który nie tylko utrudnia recepcję sztuki Warhola czy Beuysa, ale odziera ją z tego, co w niej cenne i uniwersalne. Postawa „snobowania się" na mainstream Warhola i ,śmietankę" Duchampa czy na ,alpejskie ekskursy mieszkańców zasobnych krajów arabskich"23 jest przykładem tego, co psychologia określa jako prestige-driven bias. To tendencja do przeceniania oznak prestiżu (wpływowych agentów oraz przesadnej dla nich atencji) w ogólnej ocenie dzieł (na przykład dzieło jest postrzegane jako bardziej cenne, gdy uznaje się, że jest własnością bardziej znanej galerii). Ostatnie badania na ten temat nie pozostawiają złudzeń: tak zwani eksperci od sztuki (zazwyczaj na stałe wprzęgnięci w instytucje sztuki) wpadają w pułapkę nastawienia prestiżowego znacznie częściej niż laicy. Znacznie rzadziej są też skłonni przyznać, że to właśnie oznaki statusu (na przykład imitacja pieczęci galerii MoMa na obrazie jak w eksperymencie Verpootena i Dewitte) ${ }^{24}$ oraz przemożna potrzeba elitarności (pojętej przede wszystkim w kategoriach przynależności do wyróżnionej kasty świata sztuki) kierują ich wyborami estetycznymi. A że ocena dzieł awangardy niepowiązana z prestiżem jest możliwa, pokazuje Dutton. W swej „skupiskowej” definicji sztuki „przyznaje” Fontannie 10 punktów na 12 możliwych, zwracając uwagę nie tylko na konceptualny geniusz francuskiego artysty, ale i teoretyczną adekwatność jego dzieł do założeń estetyki znaturalizowanej (odpierajac z powodzeniem zarzut marginalizowania dadaizmu i sztuki konceptualnej przez estetykę ewolucyjną).

${ }^{22}$ D. Dutton, Epilog. Nowy Renesans, [w:] Nowy Renesans, J. Brockman (red.), tłum. P.J. Szwajcer, Warszawa 2005, s. 391.

${ }^{23}$ Ł. Huculak, Sztuka i adaptacja. Adoracja, aberracja, adominacja, ,Studia Philosophica Wratislaviensia" 16 [1] (2021), s. 51.

${ }^{24}$ J. Verpooten, J. Dewitte, The Conundrum of modern art: Prestige driven coevolutionary aesthetics trumps evolutionary aesthetics among art experts, „Human Nature” 28 (2017), s. 16-38.

Studia Philosophica Wratislaviensia vol. XVI, fasc. 2, 2021

(C) for this edition by CNS 
Z pozycji elitarystyczno-instytucjonalnego estetyka - mediatora teorii i świata sztuki - Warhol to mainstream, a Duchamp to ,śmietanka”. Chociaż bliska jest mi dola i niedola estetyki, w przeciwieństwie do Bandury nie rozpływam się nad śmietanką i nie staram się za wszelką cenę płynąć z nurtem (większą przyjemność sprawiałoby mi obcowanie z każdym z jego przełomów). Doceniam natomiast zwykłe, demokratyczne w duchu, proste psychologiczne konstatacje przechodnia, w stylu: „To zrobiłby pięciolatek!” (uważam je zresztą za palące wyzwanie teoretyczne dla badań estetycznych o charakterze eksperymentalnym, których wyniki dadzą nadzieję na zrozumienie tego, ,jak działa sztuka”). Ulegają im nie tylko „ogłupiałe masy”, jak chcieliby tego instytucjonaliści, ale choćby rodziny znanych artystów, jak matka malarza Franza Kline'a, która po obejrzeniu wystawy jego czarno-białych płócien w Egan Gallery w Nowym Jorku miała powiedzieć: „Mogłam się spodziewać, Franz, że pójdziesz na łatwiznę". Gdy John Cage spytał swoją matkę, jak podoba się jej „,ta nowa muzyka” (chodziło o rock-and-roll), Lucretia „Crete', niegdyś redaktorka działu kulturalnego w „Los Angeles Times”, nie owijała w bawełnę: „Ach, wiesz John, jeśli chodzi o muzykę, nie jestem zbyt wybredna”. A po chwili, ożywiając się, dodała: „Ty, zdaje się, też nie jesteś”25. Cage, niekwestionowany lider amerykańskiej awangardy, który z dystansem traktował nie tylko swoje artystyczne posłannictwo, ale i instytucję sztuki, w innej z anegdot z tomu Rok od poniedziałku dostrzega drugie dno praktyk wartościowania sztuki współczesnej: W niedzielę po południu [podczas koncertu] obok mojej matki usiadła kobieta, która reagowała szczególnie gwałtownie. Przeszkadzała wszystkim dookoła. Po koncercie Matka zwróciła się do niej i powiedziała: „Jestem matką kompozytora”. „Boże drogi! — odparła kobieta — Muzyka pani syna jest cudowna! Czy zechce mu pani powiedzieć, jak bardzo mi się podobała?" 26

Anegdota nie tylko daje namiastkę buddyjskiego usposobienia autora 4'33", ale przede wszystkim ilustruje fakt, że miejsce dzieła sztuki w świecie (sztuki) zależy w ogromnej mierze od nadania mu statusu elitarności (wyrażonego między innymi w hermetycznym języku estetyki/teorii). Ponieważ te powszechnie pożądane w społeczeństwie walory można osiągnąć również innym sposobami (tworzenie sztuki i przynależność do „świata sztuki” to zresztą nie najbardziej spektakularne z nich), okazuje się, że jedynie mój „przechodzień” gotów jest bezceremonialnie przyznać, o co naprawdę toczy się tu gra (estetyk natomiast broni swej wieży z kości słoniowej jak niepodległości).

Przewrażliwienie Autorki na punkcie rzekomego zideologizowania dyskursu oraz szczególna atencja dla instytucjonalnej hierarchii w świecie sztuki (,Piszę te słowa z pozycji gatunku zagrożonego wymarciem") ${ }^{27}$, ufundowanej w dużej mierze na owym dyskursie (,Ponieważ instytucja jest wewnątrz nas, a nie możemy porzucić samych siebie" - to z innego tekstu Autorki, którego teza zawarta jest w jego tytule: Nie ma ucieczki od instytucji) ${ }^{28}$, to swoista licentia poetica Bandury.

25 J. Cage, Rok od poniedziałku, tłum. P. Sommer, „Literatura na Świecie” 1-2 (1996), s. 118, 120.

${ }^{26}$ Ibidem, s. 117-118.

27 A. Bandura, Twórczość jako adaptacja?, s. 39.

28 A. Bandura, Nie ma ucieczki od instytucji, „Dyskurs: pismo naukowo-artystyczne ASP we Wrocławiu" 16 (2016): 16 (2013), s. 313. 
Tłumaczy też poniekąd emocjonalną reakcję na oldskulowe pojęcie „wapory”, które zapożyczyłem od Dissanayake. Pojęcie to jak w soczewce skupia bolączki trapiące naszą estetykę, które tak barwnie odmalował Flaubert, opisując światopoglądowy spór swych bohaterów, Bouvarda i Pécucheta:

Pécuchet był za uczuciem i myślą, Bouvard za obrazem i kolorytem; i zaczynali nie zgadzać się ze sobą, każdy przy tym dziwił się, że drugi jest taki ograniczony. Nauka, zwana estetyką, być może, rozstrzygnie ich różnice zdań. Znajomy Dumouchela, profesor filozofii, przysłał im wykaz dzieł w tej materii. Pracowali osobno i dzielili się swymi rozważaniami. [...]

Istnieją różne gatunki Piękna: Piękno w naukach; geometria jest piękna. Piękno w obyczajach: nie można zaprzeczyć, że śmierć Sokratesa była piękna. Piękno w świecie zwierzęcym: piękno psa polega na jego węchu. Świnia nie może być piękna ze względu na swą niechlujność, wąż również, gdyż budzi w nas niskie myśli. Kwiaty, motyle, ptaki mogą być piękne. Wreszcie pierwszym warunkiem piękna jest jedność w różnorodności, oto zasada. - A przecie — rzekł Bouvard — para oczów zezowatych różni się od siebie bardziej niż para oczów normalnych i zazwyczaj wywołuje mniej dobre wrażenie. [...]

Zbyt ścisłe stosowanie Prawdy szkodzi Pięknu, a wyłączne zaprzątanie umysłu Pięknem przeszkadza ujawnieniu się Prawdy; jednakże bez ideału nie ma Prawdy; dlatego to typy mają w sobie rzeczywistość trwalszą niż portrety. Sztuka zresztą zajmuje się tylko prawdopodobieństwem, ale prawdopodobieństwo zależy od tego, kto je postrzega, jest rzeczą względną, przemijającą. [...]

Wątpliwości nękały go, gdyż jeśli umysły mierne (jak to zauważył Longin) są niezdolne do popełniania błędów, błędy należą do mistrzów i trzeba będzie je podziwiać. To już za wiele. A jednak mistrzowie są mistrzami. Pragnąłby pogodzić doktryny z dziełami, krytyków z poetami, podchwycić istotę Piękna; i te zagadnienia tak go dręczyły, że wpłynęło to na stan jego zdrowia. Dostał żółtaczki ${ }^{29}$.

„Wapory” to wprawdzie nie żółtaczka, ale dolegliwość przewlekła (nawet jeśli wydumana). Ozdrowieńcza „dewaporyzacja” estetyki byłaby zatem wyrazem postawy, której nie obejmuje żadna z przywoływanych przez Bouvarda koncepcji (a którą podzielam wraz z autorką Art and Intimacy, pamiętająca zapewne czasy, gdy użycie pojęcia „wapory” związane było z dyskryminacją ze względu na płeć). Polega ona na nienarzucaniu sztuce - tej wyewoluowanej, uniwersalnej kategorii, będącej swoistym rodzajem naturalnym (również w świetle badań prehistorii ludzkich zachowań artyfikacyjnych) — sztucznych, względnych historycznie, mocno zakorzenionych w kontekstach znaczeń, będących wyrazem preferencji i uprzedzeń poszczególnych autorów, ale również niedyskryminowaniu jej przypadkowych odbiorców. Lektura tekstu Bandury (niczym spór Bouvarda i Pécucheta) wywołuje dojmujące wrażenie, że estetyka, mimo deklarowanej otwartości, potrafi być w gruncie rzeczy mocno wykluczająca.

Gubili się w ten sposób w rozumowaniach. Bouvard coraz mniej wierzył w estetykę. — Jeżeli to nie jest blaga, jej ścisłość okażą przykłady. Więc słuchaj. I przeczytał notatkę, która kosztowała go dużo poszukiwań. „Bouhours oskarża Tacyta, że nie ma on prostoty, której wymaga Historia. Pewien profesor, Dróż, gani Szekspira za jego mieszaninę powagi z błazeństwem. Nisard, inny profesor, uważa, że Andre Chenier stoi jako poeta poniżej XVII wieku. Blair, Anglik, ubolewa nad obrazem Harpij u Wirgiliusza. Marmontel załamuje ręce nad licencjami Homera. Lamotte nie uznaje wielkości jego bohaterów. Vida oburza się jego porównaniami. Słowem, wszyscy fabrykanci retoryk, poetyk i estetyk wydają mi się durniami! — Przesadzasz! — rzekł Pecuchet ${ }^{30}$.

\footnotetext{
${ }^{29}$ G. Flaubert, Bouvard $i$ Pècuchet, s. 152-154.

${ }^{30}$ Ibidem, s. 154.
} 
Podzielając diagnozę Flauberta, odnoszę wrażenie, że aby przywrócić estetykę do życia po (post)modernej dewaluacji, wydobywając ją z egzystencjalnych lęków i historycznych klęsk, również w odniesieniu do formy toczonych sporów (choć to kwestia, w gruncie rzeczy, marginalna), przydałaby się odrobina unaukowienia. Żywię zatem niesłabnącą nadzieję, że wśród czytelników mojej książki znajdują się tacy, którzy mniej są wyczuleni na punkcie „stanów permanentnego niezadowolenia” czy „dróg naznaczonych niepowodzeniem i przykrością”, a bardziej skłonni, aby zaufać nauce opartej na doświadczeniach i obserwacji.

Na koniec jeszcze dwie uwagi natury metodologicznej. Wbrew temu, co głosi Bandura, czytelnik nie znajdzie w mojej książce twierdzenia, że sztuka jest adaptacją per se (żadne z wielu przytaczanych przeze mnie badań nie daje podstaw do sformułowania takiej hipotezy). Tytułową kategorię traktuję jako ideę regulatywną (co zauważa Piotr Przybysz), a nie jako postulat normatywny. Pojęcie adaptacji rozumiem tak, jak stosująca je psychologia ewolucyjna, a przed nią etologia. Aby daną cechę lub zachowanie można było określić tym terminem, muszą one spełniać bardzo „sztywne”, „wyśrubowane” kryteria. Sztuka z pewnością ich nie spełnia. Nie oznacza to, rzecz jasna, że nie można zasadnie mówić o sztuce jako o elemencie ludzkiego wyposażenia umysłowego, nabytego w toku ewolucji (albo w koewolucji z innymi mechanizmami adaptacyjnymi), jak to właśnie czyni estetyka ewolucyjna. Broniąc w książce „słabszej” tezy o „adaptacyjności” sztuki, weryfikuję ją przez analizę i badanie różnych form ,uniwersalizmu sztuki”. Międzykulturowa uniwersalność występowania cechy lub zachowania jest jednym z pośrednich (choć nie rozstrzygających) dowodów na poparcie tezy o prehistorycznych i ewolucyjnych jej źródłach (inne to: korelacja z instynktowną reakcją emocjonalną, ujawnianie się cechy na wczesnym etapie ontogenezy, oraz występowanie neuronalnego podłoża cechy). Natomiast zastosowane przez Bandurę określenie adaptacji w znaczeniu rozszerzonym, oderwane od terminologii ewolucyjnej, jako przystosowanie do warunków społecznych, kulturowych czy środowiskowych, jest błędem pojęciowym.

Sądzę również (a uwaga ta ma charakter postulatu), że aby teoretyzować o przedmiocie, nie trzeba być w przedmiocie rozmiłowanym. Można mieć obsesję na punkcie „przypadków granicznych” w sztuce, wykazywać „estetyczną skłonność do minimalizmu, abstrakcji, znalezisk, śmieci", nie czerpiąc jednocześnie przyjemności z obcowania z nimi; można też, odwrotnie, analizować jakieś zagadnienie, uznając to zajęcie za mało produktywne, teoretycznie jałowe, nieinspirujące lub po prostu mało ciekawe, i jednocześnie pozostawać dozgonnym miłośnikiem dadaizmu, sztuki konceptualnej czy muzyki aleatorycznej. Zapewne otrę się o banał, twierdząc, że postawa taka nie wpłynie w żadnym stopniu na głębię myśli, a brak stosunku emocjonalnego może jedynie tę myśl wyostrzyć. Współczesny artysta, jak bodaj nikt z jego poprzedników, jest wyjątkowo (samo)świadomy teoretycznie. Nadbudowa konceptualna znacznej części sztuki najnowszej imponuje głębią, autentyzmem, wnikliwością. Napotykane dziś dzieła analizujemy pod kątem pomysłu, założeń, konceptu. Prowadzimy filozoficzny dialog z artystą. Wchodzimy w szranki z jego wizja świata, stosunków międzyludzkich, poglądami społecznymi, politycznymi, jego wiedzą naukową, wrażliwością i wizją twórczą (dlatego sztukę współczesną postrzega się jako działalność przede wszystkim intelektualną i krytyczną, w nikłym 
stopniu estetyczną). Przewidział to sam Cage, ogłaszając, że ,filozofia dla artysty dziś jest tym, czym Biblia dla księdza"31. Paradoksalnie, niewiele z tego da się jednak powiedzieć o większości współczesnych estetyk, zwłaszcza tych konkurujących na dyskursy z artystami. W pełni podzielam diagnozę Barnetta Newmana, zawartą w motcie do tego tekstu, konstatującą ten przykry rozdźwięk. Idę też o zakład, że gdyby współczesne teorie estetyczne wykazały choć odrobinę ornitologicznej precyzji, z atencją artystów (i teoretyków) nie miałyby żadnego problemu.

\section{Bibliografia}

Bandura A., Nie ma ucieczki od instytucji, „Dyskurs: pismo naukowo-artystyczne ASP we Wrocławiu" 16 (2016): 16 (2013), s. 308-320.

Bandura A., Twórczość jako adaptacja? Sztuka zagrożona wyginięciem..., „Studia Philosophica Wratislaviensia" 16 [1] (2021), s. 39-48.

Barnett Newman: Selected Writings and Interviews, J.P. O'Neill (ed.), New York 1990.

Cage J., Rok od poniedziałku, tłum. P. Sommer, „Literatura na Świecie” 1-2 (1996), s. $111-122$.

Dewey J., Art as Experience, New York 1934 [wyd. pol. Sztuka jako doświadczenie, tłum. A. Potocki, Wrocław 1975].

Dissanayake E., The Arts after Darwin. Does art have origin and adaptive function, [w:] World Art Studies: Exploring Concepts and Approaches, K. Zijlmans, W. van Damme (eds.), Amsterdam 2008, s. 241-263.

Dutton D., Epilog. Nowy Renesans, [w:] Nowy Renesans, J. Brockman (red.), tłum. P.J. Szwajcer, Warszawa 2005, s. 390-393.

Dutton D., Sztuka i rzeczywistość ludzka, tłum. J. Luty, Racjonalista.pl, www.racjonalista.pl/kk.php/s,6977.

Flaubert G., Bouvard i Pècuchet, tłum. W. Rogowicz, Warszawa 1955.

Huculak Ł., Sztuka i adaptacja. Adoracja, aberracja, adominacja, „Studia Philosophica Wratislaviensia" 16 [1] (2021), s. 49-61.

Luty J., Estetyka ewolucyjna: sztuka jako adaptacja w ujęciu międzykulturowym, „Estetyka i Krytyka" 21 (2011), s. 101-114.

Luty J., John Cage. Filozofia muzycznego przypadku, Wrocław 2011.

Luty J., Sztuka jako adaptacja: uniwersalizm w estetyce ewolucyjnej, Kraków 2018.

Miłkowski M., Perspektywy ewolucjonistyczne w badaniach społecznych, [w:] Oprogramowanie rzeczywistości społecznej, M. Gdula, L.M. Nijakowski (red.), Warszawa 2014, s. 185-208.

Nanay B., Aesthetics as Philosophy of Perception, OUP (2016).

Verpooten J., Dewitte J., The Conundrum of modern art: Prestige driven coevolutionary aesthetics trumps evolutionary aesthetics among art experts, „Human Nature” 28 (2017), s. 16-38.

${ }^{31}$ Por. J. Luty, John Cage. Filozofia muzy cznego przypadku, Wrocław 2011, s. 145-146. 